https://doi.org/10.18778/1509-877X.2019.01.01

\title{
CZASOWY ZAKRES STOSOWANIA PRZEPISÓW KLAUZULI OGÓLNEJ PRZECIWKO UNIKANIU OPODATKOWANIA NA GRUNCIE PODATKÓW DOCHODOWYCH
}

Streszczenie. Celem artykułu jest ustalenie czasowego zakresu stosowania przepisów klauzuli ogólnej przeciwko unikaniu opodatkowania w odniesieniu do podatków dochodowych. Najważniejsze dla tego zagadnienia jest ustalenie, kiedy w podatkach dochodowych powstaje korzyść podatkowa. W ocenie autorów korzyść podatkowa w podatkach dochodowych może powstać już w trakcie roku podatkowego.

W związku z tym w świetle przepisów intertemporalnych ustawy wprowadzającej do systemu prawnego klauzulę ogólną przeciwko unikaniu opodatkowania, jeśli podatnik dokonał czynności, których skutkiem jest zaliczenie określonych kosztów do kosztów uzyskania przychodów bądź też niepowstanie (zaniżenie) przychodów, a moment potrącenia przez podatnika kosztów czy też dzień, w którym powstałby przychód podatkowy, przypadają na okres przed wejściem w życie klauzuli, regulacje te nie mają zastosowania do tego rodzaju stanów faktycznych.

Słowa kluczowe: GAAR, klauzula ogólna przeciwko unikaniu opodatkowania, podatki dochodowe, unikanie opodatkowania

* Profesor nauk prawnych, kierownik Katedry Prawa Podatkowego, Wydział Prawa i Administracji, Uniwersytet Łódzki, e-mail: wnykiel@wpia.uni.lodz.pl

** Doktor nauk prawnych, adiunkt Katedry Prawa Podatkowego, Wydział Prawa i Administracji, Uniwersytet Łódzki, doradca podatkowy, radca prawny, autor podcastu „Dzień Dobry Podatki”, e-mail: mwilk@wpia.uni.lodz.pl 
Z dniem 15 lipca 2016 r. do polskiego systemu podatkowego wprowadzono klauzulę przeciwko unikaniu opodatkowania (dalej: Klauzula). Jej kształt normatywny wyznaczony został przez regulacje zawarte w Rozdziale 1 Działu IIIA Ustawy z dnia 29 sierpnia 1997 r. Ordynacja podatkowa ${ }^{1}$ (art. 119a-119zf o.p.). Ordynacja podatkowa w tym zakresie została znowelizowana Ustawą z dnia 23 października 2018 r. o zmianie ustawy o podatku dochodowym od osób fizycznych, ustawy o podatku dochodowym od osób prawnych, ustawy - Ordynacja podatkowa oraz niektórych innych ustaw $^{2}$. Regulacjami Rozdziału 1 Działu IIIA o.p. wprowadzono normatywne pojęcie unikania opodatkowania, którym stosownie do art. 119a $\$ 1$ o.p. jest dokonanie czynności sprzecznej w danych okolicznościach z przedmiotem lub celem ustawy podatkowej lub jej przepisu, gdy głównym lub jednym z głównych celów jej dokonania było osiągnięcie korzyści podatkowej, o ile sposób działania był sztuczny ${ }^{3}$.

Jak już wspomniano, przepisy art. 119a-119zf o.p. weszły w życie 15 lipca 2016 r., tj. 30 dni od ogłoszenia Ustawy z dnia 13 maja 2016 r. o zmianie ustawy - Ordynacja podatkowa oraz niektórych innych ustaw ${ }^{4}$, którą wprowadzono te regulacje do Ordynacji podatkowej (art. 9 Ustawy nowelizacyjnej). Klauzula przeciwko unikaniu opodatkowania ma szczególny charakter. Artykuł 119 i n. o.p. pozwalają bowiem organom podatkowym na zignorowanie - z punktu widzenia ustalenia zakresu obowiązku podatkowego - ważnych i skutecznych czynności prawnych dokonanych przez podatników. Z tych względów konieczne, a zarazem bardzo ważne było odpowiednie uregulowanie zakresu czasowego obowiązywania przepisów Klauzuli.

1 Tekst jedn. Dz.U. z 2019 r., poz. 900 ze zm. (dalej: o.p.).

2 Dz.U. z 2018 r., poz. 2193; por. W. Nykiel, Nowe przepisy dotyczace klauzuli przeciw unikaniu opodatkowania - wybrane aspekty legislacyjne, [w:] Współczesne problemy prawa podatkowego. Teoria i praktyka, t. 1: Księga jubileuszowa dedykowana Profesorowi Bogumiłowi Brzezińskiemu, Warszawa 2019, s. 382 i n.

${ }^{3} \mathrm{Na}$ gruncie pierwotnego brzmienia art. 119a $\$ 1$ o.p. unikanie opodatkowania definiowane było jako dokonanie czynności przede wszystkim w celu osiągnięcia korzyści podatkowej, sprzecznej w danych okolicznościach z przedmiotem i celem przepisu ustawy podatkowej. Dokonanie takiej czynności nie skutkowało osiągnięciem tej korzyści podatkowej, o ile sposób działania był sztuczny.

${ }^{4}$ Dz.U. z 2016 r., poz. 846, dalej: Ustawa nowelizacyjna. 
Ten niezwykle istotny element regulacji Klauzuli unormowano w art. 7 Ustawy nowelizacyjnej, zgodnie z którym „przepisy art. 119a-119f ustawy zmienianej w art. 1 mają zastosowanie do korzyści podatkowej uzyskanej po dniu wejścia w życie niniejszej ustawy”.

W związku z tym istotnego znaczenia nabiera problem ustalenia sposobu wykładni tej regulacji prawnej w kontekście czynności dokonanych przed wejściem w życie klauzuli ogólnej przeciwko unikaniu opodatkowania, ze szczególnym uwzględnieniem ich skutków na gruncie podatków dochodowych - rozliczanych w okresach rocznych.

\section{INTERPRETACJE INDYWIDUALNE PRAWA PODATKOWEGO} - KSZTAŁT PRZEPISÓW INTERTEMPORALNYCH

Częstą praktyką podatników planujących dokonanie określonych czynności restrukturyzacyjnych, zwłaszcza gdy przepisy prawa podatkowego pozostawiały możliwości zróżnicowanej wykładni, było minimalizowanie ryzyka podatkowego poprzez uzyskanie interpretacji indywidualnej prawa podatkowego. W części przypadków interpretacje te zabezpieczały elementy planowanych działań restrukturyzacyjnych, które potencjalnie mogłyby być przedmiotem postępowania podatkowego zmierzającego do zastosowania Klauzuli.

Trzeba podkreślić, że stosownie do art. 14k $\$ 1$ o.p. „zastosowanie się do interpretacji indywidualnej przed jej zmianą, stwierdzeniem jej wygaśnięcia lub przed doręczeniem organowi podatkowemu odpisu prawomocnego orzeczenia sądu administracyjnego uchylającego interpretację indywidualną nie może szkodzić wnioskodawcy, jak również w przypadku nieuwzględnienia jej w rozstrzygnięciu sprawy podatkowej”. Zgodnie zaś $\mathrm{z}$ art. 14k $\$ 3$ o.p. „W zakresie związanym z zastosowaniem się do interpretacji, która uległa zmianie, której wygaśnięcie stwierdzono, lub interpretacji nieuwzględnionej w rozstrzygnięciu sprawy podatkowej, nie wszczyna się postępowania w sprawach o przestępstwa skarbowe lub wykroczenia skarbowe, a postępowanie wszczęte $\mathrm{w}$ tych sprawach umarza się oraz nie nalicza się odsetek za zwłokę".

W świetle art. $14 \mathrm{~m} \$ 1$ o.p. zastosowanie się do interpretacji, która następnie została zmieniona, której wygaśnięcie stwierdzono bądź która nie została uwzględniona $\mathrm{w}$ rozstrzygnięciu sprawy podatkowej, może powodować zwolnienie z obowiązku zapłaty podatku, w szczególności o ile skutki podatkowe związane ze zdarzeniem, któremu odpowiada stan faktyczny 
będący przedmiotem interpretacji, miały miejsce po opublikowaniu interpretacji ogólnej albo po doręczeniu interpretacji indywidualnej.

Oznacza to, że mimo wprowadzenia do systemu prawa podatkowego art. 119a i n. o.p., a tym samym umożliwienia organom podatkowym wydania decyzji kwestionującej ważne i skuteczne czynności prawne dokonane przez podatnika, jeśli podatnik dysponuje interpretacją indywidualną, w określonych okolicznościach (po spełnieniu przesłanek określonych w art. 14k czy art. $14 \mathrm{~m}$ o.p.), będzie zwolniony od zapłaty podatku. Ponieważ w istotny sposób mogłoby to obniżać skuteczność przepisów wprowadzających Klauzulę, ustawą nowelizacyjną zmodyfikowano również przedstawiony wyżej zakres ochrony interpretacji indywidualnych.

Ustawą nowelizacyjną dodano art. 14na, w świetle którego m.in. wskazanych wyżej przepisów art. 14k i 14m nie stosuje się, jeśli stan faktyczny lub zdarzenie przyszłe będące przedmiotem interpretacji indywidualnej stanowi element czynności będących przedmiotem decyzji wydanej m.in. z zastosowaniem art. 119a o.p. Zasada ta oznacza, że chociaż podatnik dysponuje interpretacją indywidualną, potwierdzającą prawidłowość przyjętego sposobu rozliczenia podatkowego planowanych transakcji, to interpretacja ta nie uchroni go przed zakwestionowaniem podjętych działań (i cofnięcia korzyści podatkowych, które w związku z tym uzyskał) w razie wydania decyzji w postępowaniu „klauzulowym”.

Podobnie jak w przypadku art. 119a i n. o.p., tak i w odniesieniu do art. 14na o.p. konieczne było wyznaczenie czasowych granic stosowania tego przepisu. $\mathrm{W}$ art. 5 ust. 1a Ustawy nowelizującej przesądzono, że art. 14na ma zastosowanie do interpretacji indywidualnych wydanych przed 15 lipca 2016 r., o ile „korzyść podatkowa wynikająca ze stanu faktycznego lub zdarzenia przyszłego będącego przedmiotem interpretacji indywidualnej została uzyskana od dnia 1 stycznia 2017 r.”.

W konsekwencji zasadniczego znaczenia nabiera wyznaczenie czasowych granic stosowania wyżej przywołanych przepisów intertemporalnych.

\section{ZASADY USTALANIA MOMENTU UZYSKANIA KORZYŚCI PODATKOWEJ}

Dla ustalenia znaczenia pojęcia „korzyść podatkowa” należy się odwołać do art. 3 pkt 18 o.p., w którym zdefiniowano to pojęcie. Zgodnie z tym przepisem korzyścią podatkową jest:

„a) niepowstanie zobowiązania podatkowego, odsunięcie w czasie powstania zobowiązania podatkowego lub obniżenie jego wysokości, 
b) powstanie lub zawyżenie straty podatkowej,

c) powstanie nadpłaty lub prawa do zwrotu podatku albo zawyżenie kwoty nadpłaty lub zwrotu podatku,

d) brak obowiązku pobrania podatku przez płatnika, jeżeli wynika on z okoliczności wskazanych w lit. a"5.

Mimo że art. 3 o.p. ogranicza zakres stosowania definicji legalnej pojęcia korzyści podatkowej do samej Ordynacji podatkowej (poprzez posłużenie się formułą , „ilekroć w ustawie jest mowa o”), to nie ulega wątpliwości, że dla zachowania spójności systemowej konieczne jest przyjęcie takiego samego rozumienia tego pojęcia także $\mathrm{w}$ przepisach intertemporalnych zawartych w Ustawie nowelizacyjnej ${ }^{6}$. Regulacje te również, w naszej ocenie, wyznaczają kształt normatywny klauzuli przeciwko unikaniu opodatkowania.

Ordynacja podatkowa korzyść podatkową rozumie szeroko (co może być uzasadnione celami, jakim ma służyć Klauzula i inne przepisy przeciwdziałające unikaniu opodatkowania, posługujące się terminem korzyści podatkowej) i obejmuje tym pojęciem każdy przypadek, w którym poprawia się sytuacja podatkowa danego podatnika (w tym też w postaci odsunięcia w czasie powstania zobowiązania podatkowego - co wyróżnia rozumienie korzyści podatkowej w świetle przepisów polskiej klauzuli ogólnej przeciwko unikaniu opodatkowania na tle unijnej koncepcji nadużycia w podatku od wartości dodanej, w przypadku której z orzecznictwa Trybunału Sprawiedliwości Unii Europejskiej (TSUE) wynika, że samo odsunięcie w czasie zobowiązania podatkowego nie stanowi nadużycia prawa ${ }^{7}$ ). Korzyścią podatkową jest zatem sytuacja, w której zmniejsza się wysokość zobowiązania, nie powstaje w ogóle zobowiązanie, powstaje bądź zwiększa się strata podatkowa, powstaje nadpłata lub prawo do zwrotu podatku bądź kwoty te ulegają podwyższeniu, a także przypadek, w którym płatnik

${ }^{5}$ Przed 1 stycznia 2019 r. definicja korzyści podatkowej znajdowała się w art. 119e o.p., zgodnie z którym korzyścią podatkową było:

„1) niepowstanie zobowiązania podatkowego, odsunięcie w czasie powstania zobowiązania podatkowego lub obniżenie jego wysokości albo powstanie lub zawyżenie straty podatkowej;

2) powstanie nadpłaty lub prawa do zwrotu podatku albo podwyższenie kwoty nadpłaty lub zwrotu podatku".

6 Alternatywnie można byłoby rozważyć interpretowanie pojęcia korzyści podatkowej zawartego w przepisach intertemporalnych w świetle definicji tego terminu na gruncie uchylonego już art. 119e o.p., choć nie ma to znaczenia dla analizy przeprowadzonej w niniejszym artykule (kształt samej definicji uległ zmianie w nieznacznym zakresie).

7 Zob. wyrok TSUE z dnia 22 grudnia 2010 r. w sprawie C-103/09 Weald Leasing. 
pozbywa się obowiązku pobrania podatku od płatnika, o ile wynika to $\mathrm{z}$ powstania zobowiązania podatkowego, odsunięcia $\mathrm{w}$ czasie powstania zobowiązania podatkowego lub obniżenia jego wysokości.

Najistotniejsze dla stosowania przepisów intertemporalnych Ustawy nowelizacyjnej, w tym przywołanego wyżej art. 7, jest ustalenie, w którym momencie zostaje uzyskana korzyść podatkowa w rozumieniu tego przepisu. W szczególności konieczne staje się zidentyfikowanie tego momentu w podatkach o tzw. otwartym stanie faktycznym, takich jak podatek dochodowy.

W myśl art. 5 o.p. zobowiązaniem podatkowym jest wynikające z obowiązku podatkowego zobowiązanie podatnika do zapłacenia na rzecz określonego podmiotu publicznoprawnego podatku w wysokości, w terminie oraz $\mathrm{w}$ miejscu określonych $\mathrm{w}$ przepisach prawa podatkowego. $\mathrm{W}$ odniesieniu do podatków, w których zobowiązania podatkowe powstają z mocy prawa (tak jak np. w podatku dochodowym), zgodnie $z$ art. $21 \$ 1$ pkt 1 o.p. zobowiązanie powstaje $\mathrm{z}$ dniem zaistnienia zdarzenia, z którym ustawa podatkowa wiąże powstanie takiego zobowiązania. Podatek ten rozliczany jest $w$ rocznych okresach rozliczeniowych, przy czym w ciągu roku podatkowego podatnik zobowiązany jest do uiszczania miesięcznych bądź kwartalnych zaliczek. Sam podatek płatny jest zatem w postaci zaliczek lub - po zakończeniu roku podatkowego - w ramach rozliczenia rocznego (wraz ze złożeniem zeznania rocznego).

Nie oznacza to jednak, że korzyść podatkowa zostaje uzyskana dopiero wówczas. Wysokość zobowiązania podatkowego (płatnego zarówno w ramach zaliczek, jak i rozliczenia rocznego) bądź straty podatkowej wynika z czynności prawnych lub faktycznych dokonanych w trakcie roku podatkowego. Mogą to być czynności prowadzące i do powstania przychodów, i do poniesienia kosztów uzyskania przychodów.

Oznacza to, że na gruncie podatku dochodowego w wyniku zaistnienia określonego zdarzenia (np. sprzedaż udziałów, wniesienie akcji do spółki itp.) powstaje przychód lub podatnik ponosi koszty uzyskania przychodów. Ustawa podatkowa określa moment, w jakim dochodzi do powstania przychodu czy poniesienia kosztu. Poniesienie kosztu czy powstanie przychodu wpływa następnie na wysokość dochodu (bądź straty podatkowej), który jest punktem wyjścia do obliczenia podstawy opodatkowania i - ostatecznie - kwoty zobowiązania podatkowego za dany rok podatkowy (zobowiązanie podatkowe może także nie powstać - z taką sytuacją mamy do czynienia, gdy rok kończy się stratą podatkową). 
Przykładowo, jeśli za dany rok podatkowy dochód podatnika wynosi np. 100, a w związku z dokonaniem 1 czerwca danego roku podatkowego czynności, w wyniku której podatnik poniesie koszt uzyskania przychodów w wysokości 50, to korzyścią podatkową jest wprawdzie obniżenie wysokości zobowiązania podatkowego, ale korzyść ta zostaje uzyskana już w momencie poniesienia kosztu uzyskania przychodów. Korzyść ta jest możliwa do obliczenia już w tym momencie, a jej wysokość jest niezależna od pozostałych zdarzeń podatkowych w danym roku podatkowym - ma zatem odrębny i samoistny charakter. Warto przy tym zauważyć, że podatnik może w wielu przypadkach „skorzystać” z niej już w trakcie roku podatkowego, płacąc niższe zaliczki na podatek (bądź nie płacąc ich w ogóle). Przyjęcie, że korzyść zostaje uzyskana dopiero po zakończeniu roku podatkowego, oznaczałoby, że podatnik uwzględnia w rozliczeniach podatkowych w trakcie roku kategorię prawną, która jeszcze nie istnieje.

Przedmiotem opodatkowania w podatku dochodowym od osób fizycznych jest dochód rozumiany jako nadwyżka sumy przychodów z danego źródła nad kosztami ich uzyskania osiągnięta w roku podatkowym. Dochód roczny (z danego źródła przychodów) może wynikać z wielu zdarzeń gospodarczych, mających miejsce na przestrzeni całego roku podatkowego, skutkujących powstaniem przychodów oraz poniesieniem kosztów uzyskania przychodów. Suma wyników podatkowych tych zdarzeń gospodarczych ujmowana w zeznaniu rocznym składa się na wynik roczny, tj. wysokość zobowiązania podatkowego bądź straty podatkowej. Jeśli okaże się, że w konsekwencji dokonania określonej czynności („zespołu powiązanych ze sobą czynności, dokonanych przez te same bądź różne podmioty” w rozumieniu art. $119 \mathrm{f} \$ 1$ o.p.) wynik podatkowy danego zdarzenia podatkowego będzie niższy, wówczas konsekwencją będzie obniżenie wysokości zobowiązania podatkowego. Jeśli w danym roku podatkowym podatnik w ogóle nie osiągnie innych dochodów, wówczas efektem dokonania takiej czynności może być niepowstanie zobowiązania podatkowego w ogóle.

Pojęcie korzyści podatkowej stanowi element siatki pojęciowej przepisów przeciwdziałających unikaniu opodatkowania, w tym zwłaszcza klauzuli ogólnej przeciwko unikaniu opodatkowania. Ustalając moment powstania korzyści podatkowej, należy ustalić, na czym ta korzyść miałaby polegać i jakie jest jej źródło - w kontekście Klauzuli. Jeśli np. w wyniku czynności dokonanych przez podatnika (bądź inne podmioty) nie dojdzie do powstania przychodu podatkowego, a gdyby dokonano „Czynności odpowiedniej”, taki przychód by powstał, wówczas moment, w którym z tytułu dokonania 
danej operacji gospodarczej powstałby przychód, powinien być utożsamiony z momentem uzyskania korzyści podatkowej. Innymi słowy, korzyść podatkowa może zostać uzyskana w chwili poniesienia kosztu przez podatnika, ale także w momencie, w którym powstałby przychód, gdyby nie dokonanie określonych czynności ${ }^{8}$. W związku $\mathrm{z}$ tym należy przyjąć, że korzyść podatkowa może zostać uzyskana w trakcie roku podatkowego.

Tym bardziej nie znajdujemy argumentów za uznaniem, że korzyść podatkowa miałaby powstawać w momencie złożenia zeznania rocznego za dany rok podatkowy. Korzyść podatkowa powstaje niezależnie od momentu, w którym podatnik składa zeznanie roczne za ten rok - a minori ad maius - również wówczas, gdy podatnik uchybia obowiązkowi złożenia zeznania rocznego. Co więcej, zobowiązanie podatkowe powstaje w określonej wysokości - wyznaczonej przez wysokość dochodu bądź straty. Oznacza to, że dochód bądź strata powstają niezależnie od terminu i sposobu ich zadeklarowania przez podatnika w zeznaniu rocznym.

Tezę, zgodnie z którą korzyść podatkowa w podatku dochodowym może powstawać w trakcie roku podatkowego, a nie po jego zakończeniu, potwierdza też wykładnia językowa i systemowa poszczególnych przepisów wyznaczających kształt normatywny Klauzuli. Zgodnie z art. 119zfa $\$ 1$ i 4 o.p. Szef Krajowej Administracji Skarbowej na wniosek zainteresowanego może wydać decyzję określającą warunki cofnięcia skutków unikania opodatkowania, a wniosek ten „może dotyczyć więcej niż jednej korzyści podatkowej, jeżeli korzyści podatkowe zostały uzyskane w danym okresie rozliczeniowym w analogiczny sposób". W takim przypadku, stosownie do art. 119zff $\$ 2$ o.p., podstawę obliczenia opłaty od wniosku stanowi „łączna kwota korzyści podatkowych objętych wnioskiem".

Dodatkowych argumentów w tym zakresie dostarczały regulacje o.p. obowiązujące do końca 2018 r. Mimo że mają one dziś znaczenie historyczne, uważamy, że ich przedstawienie ma znaczenie dla ukazania kontekstu systemowego (przepisy te zostały zmienione bądź uchylone nie ze względu na niespójność z innymi regulacjami tworzącymi kształt normatywny Klauzuli, lecz ze względu na inne przesłanki, np. potrzebę stosowania Klauzuli także do niższych niż 100000 zł korzyści podatkowych itp.).

8 Tak też: M. Guzek, M. Stefaniak, Klauzula ogólna przeciwko unikaniu opodatkowania - reguła intertemporalna a specyfika podatków dochodowych, „Monitor Podatkowy” 2019, nr 11, s. 24. 
Artykuł 119b $\$ 1$ o.p. wyłączał zastosowanie klauzuli przeciwko unikaniu opodatkowania w sytuacji, w której „korzyść podatkowa lub suma korzyści podatkowych osiągniętych przez podmiot z tytułu czynności nie przekracza w okresie rozliczeniowym 100000 zł”. Gdyby przyjąć, że w podatkach rozliczanych okresowo (np. w podatku dochodowym) korzyść podatkowa powstaje na zakończenie danego okresu (np. za dany rok podatkowy), wówczas z natury rzeczy mogłaby powstać tylko jedna korzyść za dany rok. Odniesienie się przez ustawodawcę do „sumy korzyści podatkowych" w danym okresie rozliczeniowym wskazywało, że korzyść podatkowa może powstać już w trakcie okresu rozliczeniowego (np. roku podatkowego w podatku dochodowym).

Za takim rozumieniem pojęcia korzyści podatkowej przemawia również art. 119f o.p. Przepis ten w $\$ 1$ stanowi, że przez czynność (w rozumieniu przepisów normujących kształt Klauzuli) rozumie się także „zespół powiązanych ze sobą czynności, dokonanych przez te same bądź różne podmioty”. Należy jednak zwrócić uwagę na obowiązujący do końca 2018 r. art. 119f $\$ 2$ o.p., w myśl którego w takim wypadku „wysokość korzyści podatkowych, o której mowa w art. 119b $\$ 1$ pkt 1 , oblicza się, sumując korzyści podatkowe wynikające z tych czynności”. Zestawienie brzmienia tego przepisu $\mathrm{z}$ art. $119 \mathrm{~b} \$ 1$ pkt 1 o.p. (który stanowi o zastosowaniu Klauzuli, gdy korzyść podatkowa przekracza 100000 zł „w okresie rozliczeniowym") prowadzi do wniosku, że ustawodawca wprost zakładał, iż podatnik w danym podatku, w ramach jednego okresu rozliczeniowego może osiągać wiele korzyści podatkowych (które podlegały sumowaniu na potrzeby obliczenia limitu $\mathrm{z}$ art. $119 \mathrm{~b} \$ 1$ pkt 1 o.p.) $)^{9}$.

Jak się wydaje, tylko wykładnia, zgodnie z którą korzyść podatkowa dotycząca czynności dokonanych przed 15 lipca 2016 r. powstaje w trakcie roku podatkowego, pozwala na zachowanie zgodności z Konstytucją RP art. 7 Ustawy nowelizacyjnej. Gdyby bowiem przyjąć, że korzyść podatkowa $\mathrm{w}$ takim przypadku powstaje wraz z zakończeniem roku podatkowego,

9 Na marginesie warto zauważyć, że w obowiązującym od 1 stycznia 2019 r. art. 58a o.p. moment uzyskania korzyści podatkowej wiązany jest przez ustawodawcę z momentem dokonania czynności. Zgodnie z tym przepisem w pewnych przypadkach „organ podatkowy może odstąpić od ustalenia dodatkowego zobowiązania podatkowego, jeżeli na podstawie istniejących okoliczności oraz faktów należy przyjąć, że w momencie dokonywania czynności, których dotyczy decyzja, podatnik pozostawał w błędnym, ale usprawiedliwionym przekonaniu o zgodności uzyskanej przez niego w danych okolicznościach korzyści podatkowej z przedmiotem i celem ustawy podatkowej lub jej przepisu (dobra wiara)". 
to jeśli przed 15 lipca 2016 r. doszło do zaliczenia wydatków do kosztów uzyskania przychodów bądź powstania (niepowstania) przychodu, wówczas przepisy Klauzuli miałyby charakter retroaktywny, co samo w sobie mogłoby stanowić podstawę do odrzucenia tezy, że korzyść podatkowa powstaje po zakończeniu roku podatkowego ${ }^{10}$.

Podsumowując tę analizę, warto postawić pytanie, czy w sytuacji, w której podatnik, dokonawszy określonej czynności, zaliczył do kosztów uzyskania przychodów wydatek bądź też swoimi działaniami doprowadził do tego, że w związku z daną transakcją nie doszło do powstania przychodu, mógłby zasadnie twierdzić, że nie powstała u niego korzyść podatkowa, ponieważ rok podatkowy nie został jeszcze zakończony.

4. WNIOSKI

W świetle powyższych rozważań należy stwierdzić, że korzyść podatkowa w podatkach dochodowych może powstać $\mathrm{w}$ trakcie roku podatkowego każdorazowo, gdy dochodzi do zaliczenia kosztu do kosztu uzyskania przychodów bądź niepowstania przychodu (zaniżenia przychodu) w wyniku działań (czynności) podejmowanych przez podatnika. W związku z tym możliwe jest powstanie wielu korzyści podatkowych w trakcie danego roku podatkowego.

Tym samym przepisy intertemporalne Ustawy nowelizacyjnej należy rozumieć w taki sposób, że jeśli tylko podatnik dokonał czynności, których skutkiem jest zaliczenie określonych kosztów do kosztów uzyskania przychodów bądź też niepowstanie (zaniżenie) przychodów, a moment potrącenia tych kosztów czy dzień, w którym powstałby przychód podatkowy, przypadają na okres przed wejściem w życie przepisów klauzuli ogólnej przeciwko unikaniu opodatkowania, to regulacje te nie mają zastosowania do tego rodzaju stanów faktycznych. Przemawia za tym zarówno kontekst językowy, jak i systemowy.

10 Problematyka ustalenia zgodności z Konstytucją RP przepisów klauzuli ogólnej przeciwko unikaniu opodatkowania w świetle przepisów intertemporalnych wykracza poza zakres niniejszego artykułu; zob. szerzej w tym zakresie: opinie Rady do Spraw Przeciwdziałania Unikaniu Opodatkowania z dnia 18 grudnia 2019 r. - uchwały nr 3/2019, 4/2019 oraz 5/2019, https://www.gov.pl/web/finanse/opinie-rady (dostęp: 20.03.2020); zob. także: H. Filipczyk, Reguła intertemporalna klauzuli ogólnej przeciwko unikaniu opodatkowania w świetle standardów konstytucyjnych, „Przegląd Podatkowy” 2016, nr 9, s. 20; K. Turzyński, M. Kolibski, Reguła intertemporalna klauzuli ogólnej przeciwko unikaniu opodatkowania w świetle standardów konstytucyjnych - polemika, „Przegląd Podatkowy” 2016, nr 12, s. 21 i n. 


\section{BiBLIOGRAFIA}

Filipczyk H., Reguła intertemporalna klauzuli ogólnej przeciwko unikaniu opodatkowania w świetle standardów konstytucyjnych, „Przegląd Podatkowy” 2016, nr 9.

Guzek M., Stefaniak M., Klauzula ogólna przeciwko unikaniu opodatkowania - reguła intertemporalna a specyfika podatków dochodowych, „Monitor Podatkowy” 2019, nr 11.

Nykiel W., Nowe przepisy dotyczace klauzuli przeciw unikaniu opodatkowania - wybrane aspekty legislacyjne, [w:] Współczesne problemy prawa podatkowego. Teoria i praktyka, t. 1: Ksiega jubileuszowa dedykowana Profesorowi Bogumitowi Brzezińskiemu, Warszawa 2019.

Turzyński K., Kolibski M., Reguła intertemporalna klauzuli ogólnej przeciwko unikaniu opodatkowania w świetle standardów konstytucyjnych - polemika, „Przegląd Podatkowy" 2016, nr 12.

\section{TEMPORARY SCOPE OF APPLICATION OF THE PROVISIONS OF THE GENERAL ANTI-AVOIDANCE RULE WITH REGARD TO INCOME TAXES}

Summary. The purpose of the article is to determine the temporary scope of application of the provisions of the general anti-avoidance rule (GAAR) with regard to income taxes. It has to be determined when - as for income taxes - tax advantage arises. According to the authors, the tax benefit in income taxes may arise already during the tax year.

Therefore, in the light of the intertemporal provisions of the act introducing GAAR into the legal system, if a taxpayer has carried out actions which result in deduction of certain expenses or in the non-existence of revenues and the moment of deduction of costs by the taxpayer or the date on which the tax revenue would have arisen fall on the period before the clause came into force - these provisions do not apply to such facts.

Keywords: GAAR, general anti-avoidance rule, income taxes, tax avoidance 